\title{
REVOLUSI MENTALMEWUJUDKAN SISWA BERKEPRIBADIANMELALUI PENDIDIKAN AGAMA TERPADU
}

\author{
Demina \\ Program Studi Pendidikan Agama Islam, Jurusan Tarbiyah, STAIN Batusangkar \\ Korespondensi: Jl. Sudirman No. 137, Kuburajo, Lima Kaum, Batusangkar, Sumatera Barat \\ Email: demina_rinaldi@yahoo.co.id
}

\begin{abstract}
Mental revolution is a national movement that could be implemented in many areas including in the field of education. Teachers could implement this movement in order to inject students' character. One of the strategies to actualize mental revolution in schools is using integrated Islamic teaching. Islamic teaching is not taught separately but must be implemented integratively. The use of integrative Islamic teaching is expected that students comprehend the learning content contextually. The implementation might be done using the integration of Islamic teaching to other subject matters such as civic, sport, art, language and others. It is even could be done the use of the integration of Islamic teaching to Islamic subject matters such as fiqh, aqidah akhlaq, and Quran hadits. The use of this integration is expected to solve students' problems in their daily life.
\end{abstract}

Kata kunci:revolusi mental, kepribadian, pendidikan agama terpadu

\section{PENDAHULUAN}

$\mathrm{P}$ endidikan Agama memiliki peran penting dalam revolusi mental bangsa baik melalui pendidikan formal dan nonformal di Indonesia. Pendidikan Agama Islam merupakan salah satu mata pelajaran yang mengajarkan pengetahuan dan keterampilan agama (knowing and doing) yang diharapkan proses pembelajaran keberagamaan, dalam arti mengarah pada being a religius person dan kepribadian.

Harapan di atas seiring dengan revolusi mental yang dicanangkan oleh bapak Presiden Joko Widodo yang tertuang dalam pilar ketiga Trisakti yaitu membangun kepribadian sosial dan budaya Indonesia. Masalah besar dalam pendidikan selama ini adalah kuatnya dominasi pusat dalam penyelenggaraan pendidikan sehingga yang muncul uniform sentralistik kurikulum, model hafalan dan monolog, materi ajar yang banyak, serta kurang menekankan pada pembentukkan karakter bangsa. (Majid \& Andayani. 2004).

Pendidikan dapat diharapkan untuk membangun identitas bangsa Indonesia yang berbudaya dan beradab, menjunjung tinggi nilai-nilai moral agama yang hidup di negara Indonesia.Kondisi dilapangan, diharapkan siswa disekolah tidak hanya mengetahui tentang pendidikan agama saja namun dapat merealisasikan dan mengimplementasikan untuk diri sendiri dan sosial masyarakat karena siswa akan selalu bersentuhan dengan dunia luar mereka.

Masyarakat terkesan kehilangan kontrol, kejahatan terjadi di mana-mana 
termasuk siswa yang tawuran dan begal motor. Ada yang berpendapat hal itu terjadi karena gagalnya pendidikan di Indonesia. Kegagalan dalam pendidikan tentu juga sebuah kegagalan dalam pendidikan agama khususnya. Pendidikan Agama yang disajikan secara parsial membuat anak mengetahui banyak tentang pengetahuan agama namun masih belum konkrit dan bermakna bagi anak. Anak masih sulit untuk merealisasikan di tengah masyarakat tentang sholat, berakhlak baik,sabar dan nilai-nilai lainnya. Salah satu solusi mengatasi hal ini dengan menerapkan pembelajaran agama terpadu. Melalui pembelajaran agama terpadu anak akan mampu menghubungkan berbagai konsep, materi, mata pelajaran dengan mata pelajaran lainya.

Berbagai pendapat menyatakan tentang Pendidikan Agama Islam di sekolah di antaranya:

a. Hasil belajar PAI di sekolah-sekolah belum sesuai dengan tujuan-tujuan PAI.

b. Soedijarto (1993) pendidikan nasional belum sepenuhnya mampu mengembangkan manusia Indonesia yang religius, berakhlak, berwatak ksatria dan patriotik.

c. Nurcholis Majid berpendapat kegagalan pendidikan agama disebabkan pembelajaran PAI lebih menitik beratkan pada hal-hal yang bersifat formal dan hafalan bukan pada pemaknaannya.

d. Arief Rahman pendidikan kita lebih menekankan pada kemampuan berbahasa (verbal) dan kemampuan menghitung (numerik), sementara kemampuan mengendalikan diri dan penanaman keimanan diabaikan.

e. Karo Hukum dan Humas DEPAG, RI mengutip pernyataan Presiden RI menyatakan bahwa: Pendidikan Agama belum berhasil dengan baik, salah satu indikatornya adalah masih banyaknya kejadian perkelahian antar pelajar terutama di Jakarta. f. Husni Rahim: penyampaian materi akhlak di sekolah oleh guru-guru yang diberikan kepada siswa hanya sebatas teori, padahal yang diperlukan adalah suasana keagamaan.

g. Malik Fajar (1998), menyatakan bahwa: "proses belajar mengajar sampai sekarang ini lebih banyak hanya sekedar mengejar target pencapaian kurikulum yang telah ditentukan.

h. Menteri Agama (Said Agil alMunawar) bahwa Pendidikan Agama Islam di sekolah mengalami masalah metodologi. (Majid dan Andayani, 2005: 165)

Dari hal di atas dapat diidentifikasi rendahnya kualitas pendidikan Agama Islam di sekolah, yaitu kompetensi guru masih rendah, pembelajaran lebih terfokus pada target pencapaian kurikulum dari pada pemahaman siswa, penilaian cenderung kepada aspek kognitif siswa dan waktu untuk mata pelajaran agama yang sedikit.

Merujuk dari beberapa hal di atas, maka penulis ingin memaparkan tentang revolusi mental yang mampu mewujudkan siswa yang berkepribadian melalui pembelajaran agama terpadu.

\section{PEMBAHASAN}

\section{Revolusi Mental}

Revolusi adalah perubahan sosial dan kebudayaan yang berlangsung secara cepat dan menyangkut dasar atau pokok-pokok kehidupan masyarakat. Secara umum revolusi mencakup jenis perubahan apapun yang memenuhi syarat-syarat Revolusi merupakan suatu usaha perubahan menuju kemaslahatan rakyat yang ditunjang oleh beragam faktor. Sedangkan menurut Kamus Besar Bahasa Indonesia menyebutkan revolusi adalah perubahan yang cukup mendasar dalam satu bidang, sedangkan mental adalah bersangkutan dengan batin dan watak manusia, yang bukan bersifat 
badan dan tenaga.Jadi revolusi mental adalah menyangkut keadaan kejiwaan, roh, spritual dan nilai-nilai (vested interest) yang diyakini oleh seseorang atau sekelompok orang dalam sebuah ruang lingkup kecil atau bahkan dalam sebuah negara. Keutamaan revolusi mental adalah pengetahuan praktis dalam proses pendidikan bagaimana kejujuran dan keutamaan nilai-nilai itu menjadi suatu disposisi batin ketika siswa berhadapan dengan situasi konkrit.

\section{PembelajaranTerpadu (Integratif)}

\section{Pengertian}

Pembelajaran terpadu (integratif) merupakan pendekatan pembelajaran yang mengintegrasikan berbagai kompetensi dari berbagai mata pelajaran ke dalam berbagai tema. Pengintegrasian tersebut dilakukan dalam dua hal, yaitu integrasi sikap, keterampilan dan pengetahuan dalam proses pembelajaran dan integrasi berbagai konsep dasar yang berkaitan. Tema merajut makna berbagai konsep dasar sehingga siswa tidak belajar konsep dasar secara parsial.

Rusman (2011) menyatakan pembelajaran terpadu (integrated instruction) yang merupakan suatu sistem pembelajaran yang memungkinkan siswa, baik secara individual maupun kelompok, aktif menggali dan menemukan konsep serta prinsip-prinsip keilmuan secara holistik, bermakna, dan autentik. Pembelajaran terpadu berorientasi pada praktik pembelajaran yang sesuai dengan kebutuhan dan perkembangan siswa. Dengan demikian pembelajarannya memberikan makna yang utuh kepada siswa seperti tercermin pada berbagai tema yang tersedia.

Pembelajaran terpadu merupakan suatu aplikasi salah satu strategi pembelajaran berdasarkan pendekatan kurikulum terpadu yang bertujuan untuk menciptakan atau membuat proses pem- belajaran secara relevan dan bermakna bagi anak (Atkinson, 1989).

Pembelajaran tematik adalah pembelajaran terpadu yang menggunakan tema untuk mengaitkan beberapa mata pelajaran sehingga dapat memberikan pengalaman bermakna kepada siswa. Pembelajaran tematik lebih menekankan pada keterlibatan siswa dalam proses belajar secara aktif dalam proses pembelajaran, sehingga siswa dapat memperoleh pengalaman langsung dan terlatih untuk dapat menemukan sendiri berbagai pengetahuan yang dipelajarinya. Melalui pengalaman langsung siswa akan memahami konsep-konsep yang mereka pelajari dan menghubungkannya dengan konsep lain yang telah dipahaminya. Teori pembelajaran ini dimotori para tokoh Psikologi Gestalt, termasuk Piaget yang menekankan bahwa pembelajaran haruslah bermakna dan berorientasi pada kebutuhan dan perkembangan anak.

Pembelajaran terpadu lebih menekankan pada penerapan konsep belajar sambil melakukan sesuatu (learning by doing). Dengan demikian guru perlu mengemas atau merancang pengalaman belajar yang akan mempengaruhi kebermaknaan belajar siswa. Pengalaman belajar yang menunjukkan kaitan unsurunsur konseptual menjadikan proses pembelajaran lebih efektif. Kaitan konseptual antar mata pelajaran yang dipelajari akan membentuk skema, sehingga siswa akan memperoleh keutuhan dan kebulatan pengetahuan. Selain itu, dengan penerapan pembelajaran tematik di sekolah dasar akan sangat membantu siswa, karena sesuai dengan tahap perkembangannya siswa yang masih melihat segala sesuatu sebagai satu keutuhan (holistik).

Model keterhubungan, pada prinsipnya mengupayakan dengan sengaja adanya keterhubungan konsep, keterampilan, topik, ide, kegiatan dalam satu bidang studi. Pada model ini, siswa tidak 
terlatih untuk melihat suatu fakta dari berbagai sudut pandang, karena pada model ini keterkaitan materi hanya terbatas pada satu bidang studi saja.

Dykman (1997) meneliti kurikulum terpadu. Dalam laporannya pada pelajaran yang terintegrasi, banyak siswa yang berhasil tidak hanya siswa yang sebelumnya menjanjikan akademik, tetapi juga "sangat anak-anak yang tidak memiliki dasar-dasar" (hal.25). Ini adalah bukti bahwa semua siswa bisa mendapatkan keuntungan dari pendekatan terpadu atau holistik untuk pendidikan. Dykman (1997) melanjutkan dengan menyatakan pelajaran terpadu yang sangat sukses karena "anak-anak begitu terlibat bahwa mereka tidak bisa membantu tetapi belajar"

\section{Pentingnya Pembelajaran Terpadu}

Pembelajaran terpadu penting dilaksanakan sesuai dengan perkembangan siswa dan perkembangan kurikulum, walaupun kurikulum KTSP 2006 juga sudah mencanangkan pembelajaran terpadu.Trianto (2012: 60-61) menjelaskan penting pembelajaran terpadu dalam kegiatan belajar mengajar, ada beberapa alasan yang mendasari antara lain:

a) Dunia anak adalah dunia nyata

Tingkat perkembangan mental anak selalu dimulai dengan tahap berpikir nyata. Dalam kehidupan sehari-hari, mereka tidak melihat meta pelajaran berdiri sendiri. Mereka melihat objek atau peristiwa yang didalamnya memuat sejumlah konsep atau materi beberapa mata pelajaran.

b) Proses pemahaman anak terhadap suatu konsep dalam suatu peristiwa/objek lebih terorganisir.

Proses pemahaman anak terhadap suatu konsep dalam suatu objek sangat bergantung pada pengetahuan yang sudah dimiliki anak sebelumnya. masing-masing anak selalu membangunsendiri pemahaman terhadap konsep baru. Anak menjadi arsitek pembangunan gagasan baru. guru dan orang tua hanya sebagai "fasilitator" atau mempermudah sehingga peristiwa belajar dapat berlangsung. anak dapat gagasan baru jika pengetahuan yang disajikan selalu berkaitan dengan pengetahuan yang sudah dimilikinya.

c) Pembelajaran akan lebih bermakna jika pelajaran yang sudah dipelajari siswa dapat memanfaatkan untuk mempelajari materi berikutnya. Pembelajaran terpadu sangat berpeluang untuk memanfaatkan pengetahuan sebelumnya.

d) Memberi peluang siswa untuk mengembangkan kemampuan diri.

Pengajaran terpadu memberi peluang siswa untuk mengembangkan tiga ranah sasaran pendidikan secara bersamaan. Ketiga ranah sasaran pendidikan itu meliputi sikap (jujur, teliti, tekun, terbuka terhadap gagasan ilmiah) keterampilan (memperoleh, memanfaatkan dan memilih informasi, menggunakan alat, bekerja sama, dan kepemimpinan) dan ranah kognitif (pengetahuan).

e) Memperkuat kemampuan yang diperoleh

Kemampuan yang diperoleh dari satu mata pelajaran akan saling memperkuat kemampuan yang diperoleh dari mata pelajaran lain.

f) Efisien waktu.

Guru dapat lebih menghemat waktu dalam menyusun persiapan mengajar. Tidak hanya siswa, gurupun dapat belajar lebih bermakna terhadap konsep-konsep sulit yang akan diajarkan.

\section{Tujuan Model Pembelajaran Tematik Terpadu}

Menurut Daryanto (2014: 45), Pembelajaran tematik terpadu dikembangkan untuk mencapai tujuan pembelajaran yang telah ditetapkan, dengan tujuan siswa dapat: 
a. Mudah memusatkan perhatian pada satu tema atau topik tertentu

b. Mempelajari pengetahuan dan mengembangkan berbagai kompetensi mata pelajaran dalam tema yang sama

c. Memiliki pemahaman terhadap materi pelajaran lebih mendalam dan berkesan

d. Mengembangkan kompetensi berbahasa lebih baik dengan mengkaitkan berbagai mata pelajaran lain dengan pengalaman pribadi peserta didik

e. Lebih bergairah belajar karena mereka dapat berkomunikasi dalam situasi nyata, seperti: bercerita, bertanya, menulis sekaligus mempelajari pelajaran yang lain.

f. Lebih merasakan manfaat dan makna belajar karena materi yang disajikan dalam konteks tema yang jelas

g. Guru dapat menghemat waktu, karena mata pelajaran yang disajikan secara terpadu dapat dipersiapkan sekaligus dan diberikan dalam 2 atau 3 pertemuan bahkan lebih dan atau pengayaan.

h. Budi pekerti dan moral peserta didik dapat ditumbuh kembangkan dengan mengangkat sejumlah nilai budi pekerti sesuai dengan situasi dan kondisi.

\section{Karakteristik Pembelajaran Tematik Terpadu}

Sebagai suatu proses, pembelajaran tematik terpadu memiliki karakteristik sebagai berikut:

a. Berpusat pada anak

b. Menekankan pembentukkan pemahaman dan kebermaknaan.

c. Belajar melalui pengalaman langsung.

d. Lebih memperhatikan proses dari pada hasil semata.

e. Sarat dengan muatan keterkaitan. (Daryanto)

Dari kutipan di atas dapat di jelaskan bahwa pembelajaran tematik berpusat pada siswa atau peserta didik.
Siswa dapat mengembangkan dan menghubungkan sendiri atau bersama kelompoknya untuk menghubungkan berbagai materi dengan mata pelajaran yang ada dan dengan mata pelajaran lannya.

\section{Kelebihan Pembelajaran Tematik Terpadu}

Adapun kelebihan pembelajaran tematik sebagai berikut:

1) Premis utama pembelajaran tematik terpadu bahwa siswa memerlukan peluang tambahan (additional opportunities) untuk menggunakan talentanya;

2) Menyediakan waktu bersama yang lain untuk secara cepat mengkonseptualisasi dan mensintesis;

3) Pembelajaran yang tepat untuk mengakomodasi kualitatif lingkungan belajar;

4) Menginspirasi siswa untuk memperoleh pengalaman belajar;

5) Memiliki perbedaan kualitatif (qualitatively different) dengan model pembelajarn lain, karena sifatnya memandu siswa mencapai kemampuan berpikir tingkat tinggi (higher levels thinking) atau keterampilan berpikir dengan mengoptimasi kecerdasan ganda (multiple thinking skills), sebuah proses inovatif bagi pengembangan dimensi sikap, keterampilan dan pengetahuan. (Rusman.2011)

Dapat diambil berbagai kutipan di atas bahwa pembelajaran tematik sifatnya memandu siswa mencapai kemampuan berpikir tingkat tinggi (higher levels thinking) atau keterampilan berpikir dengan mengoptimasi kecerdasan ganda (multiple thinking skills), sebuah proses inovatif bagi pengembangan dimensi sikap, keterampilan dan pengetahuan. Dalam proses pembelajaran anak diharapkan mampu mengembangkan berbagai kecerdasan yang mana setiap manusia mempunyai potensi yang dapat dikembangkan. 


\section{Pendidikan Agama Islam}

\section{Pengertian Pendidikan Agama Islam}

Menurut Zakiah Darajat (1987) Pendidikan Agama Islam adalah suatu usaha untuk membina dan mengasuh siswa agar senantiasa dapat memahami ajaran Islam secara menyeluruh. Lalu menghayati tujuan, yang pada akhirnya dapat mengamalkan serta menjadi Islam sebgaia pandangan hidup.

Pengertian Pendidikan Agama Islam adalah upaya sadar dan terencana dalam menyiapkan siswa untuk mengenal, memahami, menghayati hingga mengimani, bertagwa dan berakhlak mulia dalam mengamalkan ajaran agama islam dari sumber utamnya kitab suci Al-Qur'an dan Hadits, melalui kegiatan bimbingan pengajaran, latihan, serta penggunaan pengalaman dibarengi tuntutan untuk menghormati penganut agama dalam masyarakat hingga terwujudnya kesatuan dan persatuan bangsa. (Depdiknas. 2004).

Pengertian di atas seiring dengan rumusan UU no 20 tahun 2003 tentang sistem pendidikan nasional dalam penjelasan UUSPN mengenai pendidikan agama dijelaskan bahwa pendidikan agama dimaksud untuk membentuk siswa menjadi manusia yang beriman dan bertagwa kepada Tuhan Yang Maha Esa serta berakhlak mulia.

Dengan demikian kedudukan pendidikan agama islam sebagai mata pelajaran yang diajarkan disekolah merupakan segala upaya penyampaian ilmu pengetahuan agama islam tidak hanya untuk dipahami dan dihayati namun untuk diaplikasikan dalam ke-hidupan sehari-hari.

Penamaan bidang studi pendidikan agama Islam bukan pelajaran agama Islam adalah disebabkan berbedanya tuntutan terhadap pelajaran ini dibandingkan dengan pelajaran lainnya. Bahkan, yang diajarkan tidak cukup hanya diketahui dan diresapi saja, tetapi dituntut pula untuk diamalkan. Bahkan ada sebagian bahan tersebut yang wajib untuk dilaksanakannya, seperti sholat, puasa, zakat dan lain-lain. (AR Shaleh)

Pendidikan agama sebagai satu bidang studi merupakan kesatuan yang tidak bisa dipisahkan dengan bidang studi lainnya, karena bidang studi secara keseluruhan berfungsi tercapainya tujuan umum pendidikan nasional. Oleh sebab itu antara satu bidang studi dengan bidang studi lainnya hendaknya saling membantu dan saling kuat menguatkan dan saling menghubungkan yang disebut dengan terpadu.

Esensi pendidikan dijelaskan Azizy (2002) yaitu adanya proses transfer nilai, pengetahuan, dan keterampilan dari generasi tua kepada generasi muda agar generasi muda mampu hidup. Oleh karena itu ketika kita menyebut pendidikan Islam, maka akan mencakup dua hal, (a) mendidik siswa untuk berprilaku sesuai dengan nilai-nilai atau akhlak Islam, (b) mendidik siswa-siswi untuk mempelajari materi ajaran islam subjek berupa pengetahuan tentang ajaran Islam.

\section{Fungsi Pendidikan Agama Islam}

Kurikulum pendidikan agama Islam untuk sekolah /madrasah berfungsi sebagai berikut:

a. Pengembangan, yaitu meningkatkan keimanan dan ketaqwaan siswa kepada Allah SWT yang telah ditanamkan dalam lingkungan keluarga.

b. Penanaman nilai sebagai pedoman hidup untuk mencari kebahagian hidup didunia dan dan di akhirat.

c. Penyesuaian mental, yaitu untuk menyesuaikan dengan lingkungannya baik lingkungan fisik maupun lingkungan sosial dan dapat mengubah lingkungannya sesuai dengan ajaran agama Islam. Penyesuain mental yaitu untuk menyesuaikan diri dengan dengan lingkungannya baik lingkungan fisik maupun lingkungan 
sosial dan dapat mengubah lingkungannya sesuai ajaran agama Islam.

d. Perbaikan, yaitu untuk memperbaiki kesalahan-kesalahan, kekurangan-kekurangan dan kelemahan-kelemahan siswa dalam keyakinan, pemahaman dan pengalaman ajaran dalam kehidupan sehari-hari.

e. Pencegahan, yaitu untuk menangkal hal negatif dari lingkungannya atau dari budaya lainnya yang dapat membahayakan dirinya dan menghambat perkembangannya menuju manusia Indonesia seutuhnya.

f. Pengajaran, tentang ilmu pengetahuan keagamaan secara umum (alam nyata dan nir-nyata), sistem dan fungsionalnya.

g. Penyaluran, yaitu untuk menyalurkan anak-anak yang memiliki bakat khusus di bidang agama Islam agar bakat tersebut dapat berkembang secara optimal sehingga dapat dimanfaatkan untuk dirinya sendiri dan bagi orang lain. (Majid \& Andayani, 2004: 169-170)

Fungsi pendidikan agama Islam di atas secara jelas adalah untuk mengembangkan potensi siswa serta memiliki kepribadian yang sejati, mampu menyesesuaikan diri dengan lingkungannya serta menolak lingkungan yang tidak baik.

Menurut Sutrisno (2005: 63-69) bahwa dalam pembelajaran ada beberapa prinsip yang harus diperhatikan oleh guru, yaitu:

a) Berpusat pada siswa

b) Belajar dengan melakukan

c) Mengembangkan kemampuan social

d) Mengembangkan keingintahuan, imajinasi dan fitrah bertuhan

e) Mengembangkan keterampilan pemecahan masalah

f) Mengembangkan kreativitas siswa

g) Mengembangkan kemampuan menggunakan ilmu dan teknologi h) Menumbuhkan kesadaran sebagai warga negara yang baik

i) Belajar sepanjang hayat

j) Perpaduan kompetisi, kerja sama dan solidaritas.

Pada tingkat Sekolah Dasar dan Menengah pendekatan yang digunakan dalam Pendidikan Agama Islam adalah:

1. Pendekatan keimanan, untuk mengembangkan pemahaman adanya Tuhan sebagai sumber kehidupan makhluk sejagat.

2. Pengamalan, untuk mempraktekkan dan merasakan hasil-hasil pengamalan ibadah dan akhlak dalam menghadapi tugas-tugas dan masalah dalam kehidupan.

3. Pembiasaan, untuk membiasakan sikap dan prilaku yang sesuai dengan ajaran Islam dan budaya bangsa dalam menghadapi masalah kehidupan.

4. Rasional, usaha memberikan peranan pada rasio (akal) siswa dalam memahami dan membedakan berbagai bahan ajar dalam standar materi serta kaitannya dengan prilaku yang baik dan buruk dalam kehidupan duniawi.

5. Emosional, upaya meggugah perasaaan siswa dalam menghayati prilaku yang sesuai dengan ajaran agama dan budaya bangsa.

6. Fungsional, menyajikan bentuk semua standar materi (al-Quran, keimanan, akhlak, fiqih/ibadah dan tarikh), dari segi manfaatnya bagi siswa dalam kehidupan sehari-hari

7. Keteladanan, menjadikan figur guru agama dan nonagama serta petugas sekolah lainnya maupun orang tua siswa, sebagai cermin manusia yang berkepribadian.(Majid\&Andayani, 2004: 170-171)

Ada beberapa poin yang harus diperhatikan dalam pendidikan agama, yaitu: (a) Guru. Guru dituntut kreatif dan mampu berimprovisasi dalam pembelajaran karena kurikulum yang bagus 
belum tentu menghasilkan produk yang bagus jika kualitas gurunya rendah. (b) Proses. Proses pembelajaran tidak hanya berfokus pada aspek kognitif namun diharapkan mampu menyentuh aspek emosional (afektif) dan psikomotor. Siswa harus diberikan teori yang sejalan keteladanan. (c) Siswa. Siswa membutuhkan perhatian guru selama proses pembelajaran. Mengingat pertumbuhan dan perkembangan siswa cenderung berubah-ubah.

Ulasan di atas menjelaskan betapa pentingnya Pendidikan Agama dan guru dalam membentuk mental siswa yang bersahaja. Melalui revolusi mental perlahan dan pasti akan membentuk kepribadian siswa yang diharapkan.

\section{Konsep Pendidikan Agama Islam Terpadu di Sekolah}

Muhaimin menjelaskan interelasi Pendidikan Agama Islam dengan PKN dalam pembelajaran. Di dalam kerangka dasar dan struktur kurikulum 2006, Pendidikan Agama Islam termasuk dalam kelompok mata pelajaran agama dan akhlak mulia, yang dimaksudkan untuk membentuk peserta didik menjadi manusia yang beriman dan bertagwa kepada Tuhan Yang Maha Esa serta berakhlak mulia.

Kedekatan mata pelajaran PAI dengan PKN merupakan model keterhubungan antara satu dengan yang lain (interconnected model), yaitu adanya hubungan antara satu kompetensi dasar atau satu topik PAI dengan kompetensi dasar yang berdekatan dengan PKN dalam skema sebagai berikut:

\begin{tabular}{|l|}
\hline Kompetensi Dasar PAI \\
Aspek Al-Qur"an Hadits \\
Aspek Keiman \\
Aspek Akhlak \\
Aspek Fiqih \\
Aspek Tarikh \\
\end{tabular}

Keterpaduan Pendidikan Agama dengan mata pelajaran lainnya dalam workshop yang dilaksanakan oleh Ditjen Binbaga Islam bekerja sama dengan Fakultas Tarbiyah IAIN Sunan Kalijaga Yokyakarta. Pembahasan menyinggung pengembangan kurikulum di SMA yang menekankan pada keterkaitan antara imtak dengan 10 mata pelajaran umum. (Muhaimin. 2009: 132).

\section{Kepribadian}

Kepribadian merupakan terjemahan dari personality (Inggris), persoonalijkheid (Belanda), personalia (Perancis), personalichkeit (Jerman),

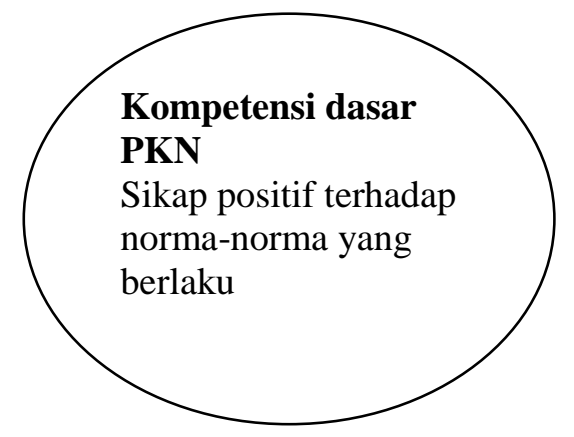

personalita (Itali), dan personalidad (spayol). Akar kata masing masing sebutan itu berasal kata latin "persona" yang berarti "topeng" sandiwara.

Istilah kepribadian dalam beberapa literatur memiliki ragam makna dn pendekatan. Sebagian psikolog ada yang menyebutnya dengan (1) personality (kepribadian) sendiri, sedang ilmu yang membahasnya disebut dengan the psychology of personality, atau Theory of personality, (2) character (watak atau perangai).

Kepribadian sering diartikan sebagai ciri-ciri yang menonjol pada diri individu seperti pemalu, supel, pengecut, egois dan sikap atau tingkah laku lain- 
nya. Abin Syamsuddin (2003) mengemukakan tentang aspek-aspek kepribadian yang di dalamnya mencakup diantaranya:

1. Karakter yaitu konsekuen tidaknya dalam mematuhi etika perilaku, konsisten tidaknya dalam memegang pendirian atau pendapat.

2. Temperamen yaitu disposisi reaktif seorang, atau cepat lambatnya mereaksi terhadap rangsangan-ransangan yang datang dari lingkungan.

3. Siakp sambutan terhadap objek yang bersifat positif, negatif atau ambivalen.

4. Stabilitas emosi yaitu kadar kestabilan reaksi emosional terhadap ransangan dari lingkungan

5. Responsibilitas (tanggungjawab) adalah kesiapan untuk menerima resiko dari tindakan atau perbuatan yang dilakukan

6. Sosiabilitas yaitu disposisi pribadi yang berkaitan dengan hubungan interpersonal

Setiap individu memiliki ciri-ciri kepribadian tersendiri, mulai dari yang menunjukkan kepribadian yang sehat atau justru yang tidak sehat. Syamsu Yusuf 2003 mengemukakan ciri-ciri kepribadian yang sehat sebagai berikut:

1. Mampu menilai diri sendiri secara realistik mampu menilai diri apa adanya tentang kelebihan dan kekurangannya, secara fisik, pengetahuan, keterampilan dan sebagainya.

2. Mampu menilai situasi secara realisitik, dapat menghadapi situasi atau kondisi kehidupan yang dialaminya secara realistik dan mau menerima secara wajar, tidak mengharapkan kondisi kehidupan itu sebagai sesuatu yang sempurna.

3. Mampu menilai prestasi yang diperoleh secara realistik, dapat menilai keberhasilan yang diperolehnya dan mereaksinya secara rasional, tidak menjadi sombong, angkuh atau mengalami superiority complex, apa- bila memperoleh prestasi yang tinggi atau kesuksesan hidup. Jika mengalami kegagalan, dia tidak mereaksinya dengan frustasi, tetapi dengan sikap optimistik.

4. Menerima tanggung jawab, dia mempunyai keyakinan terhadap kemampuannya untuk mengatasi masalahmasalah kehidupan yang dihadapinya.

5. Kemandirian, memiliki sifat mandiri dalam cara berfikir, dan bertindak, mampu mengambil keputusan, mengarahkan dan mengembangkan diri serta menyesuaikan diri dengan norma yang berlaku dilingkungannya.

6. Dapat mengontrol emosi, merasa nyaman dengan emosinya, dapat menghadapi situasi frustasi, depresi, atau stress secara positif atau konstruktif, tidak destruktif (merusak)

7. Berorientasi tujuan, dapat merumuskan tujuan-tujuan dalam setiap aktivitas dan kehidupannya berdasarkan pertimbangan secaraa matang (rasional), tidak atas dasar paksaan dari luar, dan berupaya mencapai tujuan dengan cara mengembangkan kepribadian (wawasan), pengetahuan dan keterampilan.

8. Berorientasi keluar (ektrover), bersifat respek, empati terhadap orang lain, memiliki kepedulian terhadap situasi atau masalah-masalah lingkungannya dan bersifat fleksibel dalam berfikir, menghargai dan menilai orang lain seperti dirinya, merasa nyaman dan terbuka terhadap orang lain, tidak membiarkan dirinya dimanfaatkan untuk menjadi korban orang lain dan mengorbankan orang lain, karena kekecewaan dirinya.

9. Penerimaan sosial; mau berpartsipasi aktif dalam kegiatan sosial dan memiliki sikap bersahabat dalam berhubungan dengan orang lain.

10. Memiliki filsafat hidup; mengarahkan hidupnya berdasarkan fil- 
safat hidup yang berakar dari keyakinan agama yang dianutnya.

11. Berbahagia; situasi kehidupannya diwarnai kebahagiaan, yang didukung oleh faktor-faktor achieve-ment (prestasi), acceptance (pene-rimaan), dan affection (kasih sayang).

Kepribadian yang sehat di atas dalam pembelajaran pendidikan agama terpadu dapat dikupas dan kembangkan wawasannya dalam berbagai mata pelajaran seperti hidup bersama, sabar, dan selalu mensyukuri nikmat yang diberikan Tuhan Yang Maha Esa.

\section{Kepribadian yang Tidak Sehat}

- Mudah marah (tersinggung)

- Menunjukkan kekhawatiran dan kecemasan

- Sering merasa tertekan (stress atau depresi)

- Bersikap kejam atau senang mengganggu orang lain yang usianya lebih muda atau terhadap binatang

- Ketidakmampuan untuk menghindar dari perilaku menyimpang meskipun sudah diperingati atau dihukum

- Kebiasaan berbohong

- Hiperaktif

- Bersikap memusuhi semua bentuk otoritas

- Senang mengkritik/mencemooh orang lain

- Sulit tidur

- Kurang memiliki rasa tanggung jawab

- Sering mengalami pusing kepala (meskipun penyebabnya bukan faktor yang bersifat organis)

- Kurang memiliki kesadaran untuk mentaati ajaran agama

- Pesimis dalam menghadapi kehidupan

- Kurang bergairah (bermuram durja) dalam menjalani kehidupan

Berbagai bentuk kepribadian di atas sejatinya siswa memahami dan melaksanakan dalam kehidupan sehari. Kebiasaan berkepribadian baik meru- pakan hasil dari pendidikan, untuk itu pendidikan selalu diarahkan dalam perubahan pada kepribadian baik.

\section{Hubungan Revolusi Mental, Pem- belajaran Terpadu, Pendidikan Agama dan Kepribadian}

Pembelajaran terpadu dalam pendidikan agama Islam diharapkan mampu membentuk kepribadian siswa. Hal ini seiring dengan revolusi mental yang dicanangkan Bapak Presiden Joko Widodo. Penerapan pembelajaran terpadu dalam Pendidikan Agama Islam di sekolah akan menghubungkan antar satu pelajaran dengan pelajaran lainnya. Siswa tidak hanya terfokus kepada penghafalan materi melainkan bagaimana siswa memahami materi sebagai prinsip yang harus diamalkan dalam kehidupan sehari-hari.

Pembelajaran terpadu memberi peluang siswa untuk mengembangkan tiga ranah sasaran pendidikan secara bersamaan. Ketiga ranah sasaran pendidikan itu meliputi sikap (jujur, teliti, tekun, terbuka terhadap gagasan ilmiah) keterampilan (memperoleh, memanfaatkan dan memilih informasi, menggunakan alat, bekerja sama, dan kepemimpinan) dan ranah kognitif (pengetahuan). Sehingga siswa tidak merasa terbebani dengan banyaknya materi yang harus dikuasai selama pembelajaran.

Selain itu, pembelajaran terpadu akan membangun sikap spiritual dan sosial siswa. Membangun sikap spiritual dan sosial dapat dilakukan dengan berbagai cara, antara lain:

1. Membuat kesan pertama yang menyenangkan.

2. Memahami dan mengembangkan pribadi siswa.

3. Membangun sikap spiritual dan sikap sosial dengan pengaruh.

4. Membangun sikap spiritual dan sikap sosial dengan komunikasi.

5. Membangun sikap spiritual dan sikap sosial dengan hadiah dan hukuman. 
6. Membangun sikap spiritual dan sikap sosial dengan kemanusiaan.

7. Membangun sikap spiritual dan sikap sosial dengan menghindari perdebatan.

8. Membangun sikap spiritual dan sikap sosial dengan percaya diri.

9. Membangun sikap spiritual dan sikap sosial dengan lingkungan.

10. Membangun sikap spiritual dan sikap sosial dengan kecerdasan emosional

11. Membangun sikap spiritual dan sikap sosial melalui perbaikan berkesinambungan. (Mulyasa. 2014: 103-104)

\section{PENUTUP}

Kesimpulan dari pembahasana di atas adalah pembelajaran agama terpadu dapat membentuk siswa yang berkepribadian sebagai wujud implementasi revolusi mental yang dicanangkan Bapak Presiden Joko Widodo. Berdasarkan kesimpulan di atas maka penulis mengemukakan beberapa saran, yaitu: Diharapkan pada guru-guru Pendidikan Agama agar dapat menerapkan model tematik terpadu dan dapat menggunakan model ini sesuai dengan materi yang relevan.

Pembelajaran PAI terpadu di sekolah membantu siswa memecahkan masalah, baik langsung maupun tidak dalam kehidupan nyata. Dengan pembelajaran PAI terpadu juga anak-anak dapat memaknai pelajaran mereka untuk dapat diaplikasikan di lingkungannya.

\section{DAFTAR RUJUKAN}

Abdul Majid\& Andayani Dian. 2005. Pendidikan Agama Islam Berbasis Kompetensi Konsep dan Implementasi Kurikulum 2004. Bandung: PT Remaja Rosdakarya.

Abdul Rahman Shaleh. 2005. Pendidikan Agama \& Pembangunan Watak Bangsa.PT.Raja Grafindo Persada.

Daryanto. 2014. Pembelajaran Tematik Terpadu Terintegrasi (Kurikulum 2013).GavaMedia.

Depdiknas, Kurikulum 2004 Standar Pendidikan Agama Islam Sekolah MenengahAtas dan madrasah Aliyah, Jakarta.

Dykman, A. 1997. Interview with Susan Drake. Techniques, 72 (8)

Ki Fudyartanta. 2010. Membangun Kepribadian dan Watak Bangsa
Indonesia yang Harmonis dan Integral. Pustaka Pelajar.

Muhaimin. 2009. Rekonstruksi Pendidikan Agama Islam. PT. Raja Grafindo Persada. Jakarta.

Mulyasa.2014. Guru dalam Implementasi Kurikulum 2013. Bandung: PT RemajaRosdakarya

Rusman. 2011. Model-model Pembelajaran Mengembangkan Profesionalisme Guru. Rajawali Pers.

Sutrisno. 2005. Revolusi Pendidikan di Indonesia. Yogyakarta: PT ArRuzz Media

Syamsu Yusuf 2003. Teori Kepribadian. Rosda.

Trianto. 2012. Model Pembelajaran Terpadu Konsep, Strategi dan Implementasinyadalam KTSP. 